Vol 41 (2016) No 184 91-103

\title{
Examining Department Chairs' Needs in Performing Academic Leadership in Turkish Universities
}

\author{
Mehmet Şükrü Bellibaş ${ }^{1}$, Gökhan Özaslan ${ }^{2}$, Emine Gümüş ${ }^{3}$, Sedat Gümüş ${ }^{4}$
}

\begin{abstract}
While the educational leadership literature is replete with studies focusing on leadership practices at K-12 level, higher education institutions all over the world do not receive their share from this intense scholarly interest. This is the case with Turkish higher education institutions too. Starting from this point of view, the purpose of this study is to examine department chairs' needs in performing academic leadership. To this end, the study was designed as a qualitative inquiry. In order to reveal a range of leadership experiences, maximum variation sampling was employed to address the diversity of chairs' academic leadership experiences. Accordingly, semi-structured interviews were conducted with the study group of 16 department chairs who varied in terms of their province, university type (public and foundation), teaching field, gender, and years of service in chairship position. Findings emerged in the phase of content analysis revealed that needs of department chairs can be categorized under the themes of: (a) More autonomy for decisionmaking in staff recruitment, monetary, and curricular issues (b) Additional academic and clerical personnel, and (c) Training for leadership and orientation for administrative duties.
\end{abstract}

Keywords

DOI: 10.15390/EB.2016.6114

\section{Introduction}

"Leadership" has become one of the most studied phenomena in many sectors such as business, public administration, volunteer organizations, etc., during the last several decades. Although there is no common definition of leadership, it has been generally associated with three concepts; influence, values, and vision (Bush, 2008). Most definitions of leadership emphasize the leaders' role in accomplishing organizational goals by motivating followers. Due to the attributed characteristics and powerful definitions, the concept of leadership has also become very popular in educational research, especially after 1980s. Accordingly, a substantial body of research has focused

\footnotetext{
1 (Corresponding Author) Adiyaman University, Faculty of Education, Department of Educational Sciences, Turkey, mbellibas@adiyaman.edu.tr

2 Necmettin Erbakan University, Ahmet Keleşoğlu Faculty of Education, Department of Educational Sciences, Turkey, ozaslangokhan@gmail.com

${ }^{3}$ Necmettin Erbakan University, Eregli Faculty of Education, Department of Educational Sciences, Turkey, egumus@konya.edu.tr

${ }^{4}$ Necmettin Erbakan University, Ahmet Keleşoğlu Faculty of Education, Department of Educational Sciences, Turkey, gumussed@gmail.com
} 
on leadership theories and practices at K-12 level, in order to provide principals with the guideline for effective leadership (Hallinger, 2003). Yet, there has not been much research focusing on leadership roles at the higher education level until recently (Gmelch, 2002, 2004, 2013). It could be argued that "leadership" is relatively an unknown concept in higher education settings compared to other organizational settings, including K-12 education. Gmelch (2004, p. 69) defines this situation as follows; "while the corporate world complains that it has simply progressed from the Bronze Age of leadership development to the Iron Age, we fear that in higher education, we may still be in Dark Ages".

In response to such an alarming statement, research on leadership roles, knowledge and behaviors of university administrators has emerged as a promising phenomenon in the last decade. Extant research focused substantially on two key leadership levels: deanship and department chairship. Department chairs, particularly, are at a very strategic and challenging position, since a great deal of work at universities is completed at this level (Bryman, 2007; Parker, 2014; Wolverton, Ackerman, \& Holt, 2005). Their myriad responsibilities include administrative, resource management, professional scholarship, faculty development, and resource development tasks (Carroll \& Gmelch, 1994). A good chair is also expected to know everyone in the department personally through regular communication, motivate and empower people, and become supportive to the academic work of personnel (Parker, 2014). Despite such arduous and multiple nature of their work, department chairs usually come to the position without going through any preparation for leadership and often chosen among those who are volunteer, with higher academic title or waiting for his/her turn (Gmelch, 2013; Hecht, 2000; Sirkis, 2011). For instance, Cipriano and Riccardi (2012) found that only 3.3 percent of department chairs had formal coursework related to chairship in their graduate education and only 9.1 percent had formal department management training in the USA.

Similarly, the issue of leadership is paramount for department chairs in the Turkish higher education context, since there is no formal training available to department chairs. In addition, substantial numbers of people, mostly without prior experience, have been recently assigned to leadership positions at the departmental level due to the recent increase in the universities in Turkey. While there were only 77 universities in 2005, this number was quickly boosted with the government's higher education policy to establish at least one university in every provinces beginning with 2006 (Çetinsaya, 2014; Ozoglu, Gur, \& Gumus, 2016). After this year, 116 new universities, including public and foundation (non-profit private), were established and the total number became 193 in 2015. This corresponds to the establishment of thousands of new academic departments since 2002 (YÖK, 2015). Taking into consideration the fact that the one with higher academic title typically becomes the department chair in Turkish universities (Üniversitelerde Akademik Teşkilat Yönetmeliği, 1982), this raises considerable questions and concerns regarding the effectiveness of university personnel at the chairship position.

This reality led to consider the great deal of academic and administrative problems which department chairs are more likely to face when they came to the position. However, there is only little research focusing on leadership at the higher education level in Turkey (e.g., Akbulut, Seggie, \& Börkan, 2015; Erkutlu \& Chafra, 2014; Hacifazlioglu, 2010; Korkut, 1992; Kiyik-Kicir \& Pasaoglu, 2014; Sirin \& Yetim, 2009). In addition, only a few existing studies used the specific term, academic leadership, and none of them solely focused on department chairs. Specifically, Kiyik-Kicir and Pasaoglu (2014) investigated the variation in the servant leadership behaviors of university deans and several demographic factors that account for such variations. Sirin and Yetim (2009) focused on transformational leadership behaviors of administrators working at Physical Education and Sports Schools. Some studies also specifically focused on women leadership in higher education. For instance, Hacifazlioglu (2010) compared Turkish and American women academic leaders, in terms of problems they faced in their first year of appointment to the position, and their experience of dealing with such problems. 
In sum, leadership in higher education settings, specifically academic leadership, has been understudied compared to the leadership in other settings such us business, K-12 education, public administrations, etc. However, international research on academic leadership has substantially increased in the last decade, paying special attention to the department chairs (e.g., Bowman, 2002; Bryman, 2007; Gmelch, 2002, 2004; Lieff et al., 2013; Normore \& Brooks, 2014; Sirkis, 2011; Wolverton et al., 2005), while the relevant research is still very limited in Turkey. To this end, the purpose of the present study is to explore the needs of department chairs as academic leaders in Turkish higher education institutions. Before moving to the method section, a conceptual discussion of academic leadership and relevant literature was provided.

\section{Literature Review}

\section{Definition of Academic Leadership}

As mentioned before, there exists no single agreed definition of "leadership" or "leader" among researchers. The way it is understood in the literature varies (Bush, 2011). Winston and Patterson (2006) provide a comprehensive definition through a detailed review of existing literature. According to them:

A leader is one or more people who selects, equips, trains, and influences one or more follower(s) who have diverse gifts, abilities, and skills and focuses the follower(s) to the organization's mission and objectives causing the follower(s) to willingly and enthusiastically expend spiritual, emotional, and physical energy in a concerted coordinated effort to achieve the organizational mission and objectives (p.7).

More briefly, Moore and Diamond (2000) defined leadership as capability of directing human resources to the achievement of the common goals. In an educational context, one definition of leadership could be "A process of influence leading to the achievement of desired purposes. It involves inspiring and supporting others towards the achievement of a vision for the school which is based on clear personal and professional values" (Bush \& Glover, 2003, p. 10). As it is observed in these definitions, Leithwood and Riehl (2003) argued that two important features embedded in the core definitions of leadership are providing directions and exercising influence.

Those fundamental concepts that are common in most leadership definitions also exist in the definition of academic leadership. According to Wolverton and Gmelch (2002), academic leadership is defined as "The act of building a community of scholars to set direction and achieve common purposes through the empowerment of faculty and staff" (p. 5). This definition underlines three key components of academic leadership; building a community of scholars, setting direction, and empowering others. Building a community of scholars refers to developing potential among staff in collaboratively taking part in leadership activities. Setting direction means that the leader creates a collective sense of direction toward pre-determined goals. Lastly, empowering others includes all actions performed by the leader for the purpose of motivating faculty toward continuous improvement of the performance, such as rewarding faculty, providing resources, helping them feel important, etc. (Wolverton \& Gmelch, 2002). From a different perspective, Moore and Diamond (2000) emphasized the academic leaders' role of internal and external communications to achieve goals by stating that academic leaders should be able to build connections between their staff and stakeholders in the process of creating a vision for their department and achieving it.

Although most definitions of academic leadership share some similarities with general leadership definitions, it is discussed that academic leadership has its own distinct characteristics as well. Gmelch and Buller (2015) indicated that academic leadership is different than leadership in other settings such as business, military, churches etc., in some aspects. They noted that "The concepts of collegiality and shared governance assume a much more important role in an academic setting than elsewhere" (p. 42). For example, faculty members traditionally have greater levels of autonomy and individual working arrangements. This makes it hard to establish hierarchical management structures in higher education institutions and limits the autonomy of academic leaders (Marshall, Adams, \& 
Cameron, 2001). At the same time, academic leaders mostly continue to do their research and teaching after they become the head of departments or colleges, while there is rarely any other leadership position which involves requirements of the previous position (Gmelch, 2013). Based on these unique characteristics of the chairship work, Sathye (2004) suggests that although academic leaders need to have the common attributes of leadership, they should also be able to carry out their teaching and research roles as scholars.

\section{Department Chairs as Academic Leaders}

Wolverton et al. (2005) analyzed various tasks that chairs are responsible for and categorized them into three main groups; Managerial, leadership, and balancing tasks. According to Wolverton et al. (2005), managerial issues are mostly budget related and sometimes chairs have to spend the whole day dealing with budget. Their leadership role, on the other hand, requires them to deal with the faculty in terms of professional development and ordinary problems they face every day. Finally, the balancing tasks were defined as chairs' effort to stay current in research and disciplines. Due to the nature of their task, it is possible that they may abandon one of their responsibilities in expense of others. For instance, department chairs may not be able to spend sufficient time for conducting research or keep up with the recent updates in the field due to the substantial amount of time they expend for coping with budget and faculty issues. Considering all these roles, it can be argued that chairship occupies one of the most challenging positions on university campuses (Parker, 2014). It calls for having various abilities and skills that are different from those of a scholar should possess (Wolverton \& Gmelch, 2002).

Heavy and multiple nature of the work at departmental level may not effectively be achieved without personnel who possess effective leadership skills. Bryman (2007) conducted a comprehensive review of the literature between 1987 and 2007, in order to highlight the fundamental characteristics of effective academic leaders at the chairship position. According to the review, effective department leaders are those who provide training and guidance regarding where the department should move toward; allow staff to gain a sense of autonomy by involving them in decision-making processes; influence staff by being a role model; and create an effective collegial atmosphere within the department. Similarly, Bowman (2002) pointed out that department chairs need to have multifaceted leadership skills, including "well-honed communication skills, problem-solving skills, conflictresolution skills, cultural management skills, coaching skills, and transition skills" (p. 161). Such leadership competencies, however, do not come automatically with the appointment. Therefore, there needs to be a substantial leadership training programs and job-embedded experiences in place as well as university scholars with high motivation and potential of leadership (Gmelch, 2004).

As pointed out above, researchers provided various lists consisting of multifaceted prescriptions for department chairs to be effective academic leaders. There are, however, only few universities which provide substantial leadership development opportunities for department chairs even in the USA, where the most leadership research are conducted and implemented. Pointing out the lack of preparatory leadership support for department chairs, Gmelch (2013) states;

\footnotetext{
Department chairs typically come to the position without leadership training, without prior executive experience, without a clear understanding of the ambiguity and complexity of their roles, without recognition of the metamorphic changes that occur as one transforms from an academic to a leader, and without an awareness of the cost to their academic and personal lives (p. 26).
}

In this context, some studies have investigated the needs and challenges of department chairs as academic leaders. Being a department chair is defined as paradoxical because of its crucial role in the governance of higher education institutions without a strong authority. Department chairs manage different groups - faculty, staff, and students - which have distinct interests and characteristics (Hecht, 2000; Wolverton et al., 2005). In addition, they often act as a connection between higher level of administration and faculty members as well as deal with many issues from office management to program development and from faculty/student issues to financial management 
(Hecht, Higgerson, Gmelch, \& Tucker, 1999). Among their extensive tasks, department chairs reported followings as some of the biggest challenges to their role; bureaucracy, work load, lack of time for research, non-collegial faculty members, and lack of resources (Cipriano \& Riccardi, 2012). In their study of a college of medicine, Lieff et al. (2013) found that chairs need cultural and structural awareness, a comprehensive network of people, improvement of infrastructure and professional development, and betterment in interpersonal skills to influence others.

In general, being a department chair requires greater transformation compared to the most other leadership positions because of the unique characteristics of the work. As academic leaders, department chairs should be able to carry out daily routine tasks, manage their time between administrative and scholarly requirements, and demonstrate strong human relations in an objective manner (Hecht, 2000). Given the cultural and contextual differences among departments in different institutions, more research is necessary to effectively capture the common needs of chairs. In Turkish context, there has been a lack of study on the academic leadership of department chairs. However, it is not hard to assume that department chairs in Turkey may also experience significant issues and possess specific needs. This study will help the international audience to develop an insight into the leadership problems and needs of Turkish department chairs and compare them with their own cases.

\section{Method}

Due to its explorative nature, this study was designed as a qualitative inquiry. This section of the paper starts with a description of the sampling strategy and details regarding participants. It then provides information about how the data is collected and which instrument is employed. Finally, it lays out details concerning the analysis of the collected data, reliability and validity issues.

\section{Study Group}

In this study, a purposeful sampling strategy was adopted to determine participants. Purposive sample offers an opportunity to recruit people who are the most appropriate for key questions of the research (Maxwell, 2005). Several purposive sampling strategies can be used depending on the aim of the research. The main goal of the current study was to reveal a range of academic leadership experiences of department chairs. Therefore, maximum variation sampling was employed to address the diversity of chairs' academic leadership experiences. To this end, the study group of 16 department chairs varied in terms of their province, academic title, university type (public or foundation), teaching field, gender, and years of service in chairship position. Details of study group are presented in Table 1. In order not to reveal participants' identities, their years of experience, teaching fields and names of their universities were intentionally excluded from the table.

Table 1. Details of Study Group

\begin{tabular}{lllll}
\hline Code & Academic Title & Gender & University Type & City \\
\hline P1 & Professor & Female & Public & A \\
P2 & Assoc. Professor & Female & Public & A \\
P3 & Assoc. Professor & Female & Public & A \\
P4 & Asst. Professor & Female & Public & A \\
P5 & Professor & Male & Public & A \\
P6 & Professor & Male & Public & A \\
P7 & Professor & Male & Foundation & A \\
P8 & Professor & Male & Foundation & A \\
P9 & Asst. Professor & Female & Public & B \\
P10 & Assoc. Professor & Female & Foundation & C \\
P11 & Asst. Professor & Female & Foundation & C \\
P12 & Professor & Male & Public & B \\
P13 & Assoc. Professor & Male & Public & B \\
P14 & Assoc. Professor & Male & Public & B \\
P15 & Asst. Professor & Male & Foundation & C \\
P16 & Asst. Professor & Male & Foundation & C \\
\hline
\end{tabular}




\section{Data Collection and Instruments}

The data for the study was collected through semi-structured interviews conducted face-to face with each participant. Interview questions were determined based on the literature on academic leadership. The final interview form consists of six specific open-ended questions. The first three aimed to focus on the problems that department chairs face during their managerial, leadership and balancing activities. The last three, on the other hand, focused on the types of support they need to effectively deal with the articulated problems.

Semi-structured interviews were carried out during August-September 2015, by two researchers in three distinct provinces of Turkey. At the onset of data collection, each participant was given an informed consent form which was based on the pattern developed by Creswell (2007, p. 124) in order to inform the participants of their rights. Another advice from Creswell (2007) was to receive the permission of gatekeepers. Accordingly, the interviews started after receiving official permissions from participants' faculties. Each interview was conducted in-person with and in a place shown by the participant. All interviews were digitally recorded with the permission of the participant in advance, except for one who did not accept the use of voice recorder during the interview. The interviews lasted approximately 45 minutes on average.

\section{Data Analysis}

Before the beginning of data analysis, firstly, one of the researchers transcribed the content of recorded interviews verbatim and delivered transcripts to another researcher who carried out content analysis. The content analysis took several steps. The first step was to bring out codes. The primary researcher read through each Microsoft Word document, representing each participant, and wrote codes in form of words. This gave the opportunity to summarize and synthesize what was mentioned by participants. The second step involved categorizing codes. The process of categorization revealed main and subthemes to be used in the finding section. Then, direct quotation that represented the themes and subthemes best were determined to be included in the paper. Two fundamental strategies were employed to ensure validity and reliability of the findings. First of all, in order to contribute to the validation of the analysis, other three researchers have read the transcriptions in detail and compared the analysis report to their inferences about the phenomenon. Another strategy for enhancing the rigor of the study is "review by inquiry participants" (Patton, 2002, p. 560). Within this scope, the draft of findings was sent to participants' email addresses in order to ensure the completeness and accuracy of the final report. Transcriptions were also sent to several participants on their requests.

\section{Findings}

In this section of the paper, findings related to perceived needs of department chairs while they perform their responsibilities as academic leaders were presented. Findings emerged as the results of the analysis of audio records are presented as main themes and sub-themes. For each theme, chairs' perceptions of the problems they face and associated needs were discussed. According to results, chairs' perceptions of their academic leadership needs include more autonomy in curriculum decisions, staff recruitment and monetary issues, additional academic and clerical personnel, and training for leadership and orientation for administrative duties. A detailed description of those needs is as follows.

\section{More Autonomy}

The data show that chairs are critical about the power of their positions. Many department chairs complained about their position being weakened by faculty deans. One said "In case of a problem with regard to personnel issue, the deanship sometimes gives the decision without letting chairs know (about it) (P14)." Some chairs believe that this is a case because "The dean tries to sideline chairship position (P10)." "On one hand it looks like you (chairs) have power, on the other hand you (chairs) have to accept whatever an upper position dictates (P9)." Particularly, if the dean has an academic background that is the same or compatible with the academic focus of the department, it is 
more likely that they take more control of the decision-making processes at the departmental level. As a result of this, chairs feel that chairship position suffers from the lack of power in the decisionmaking mechanism. Their sense of being powerless is substantial with regard to staff recruitment for the department, monetary issues, and curricular decisions.

\section{Staff Recruitment}

Staff recruitment is one issue in which chairs need more autonomy. Five of participants mentioned that they have no power in recruiting the most appropriate person for the department. It is usually the dean or rector that decide who should be recruited in a specific department. One participant said;

In some foreign countries, the department chair has the initiative to determine the personnel needed. The chair finds his scholar, the candidate presents references, and the chair has the power to decide whether s/he should be accepted or not. Yet, here there is inference from higher authority in the recruitment of either assistant or professor. The administration, that is the dean, should support us and get our opinion because it is us (chairs) who are the primary addressee of students and parents in case of a problem (P10).

From the data, it is evident that the chairs want to possess some power in deciding whom they are going to work with. Otherwise they have to work with someone who does not fit the need of department well. For instance, a chair said "The rector wanted to recruit a person that we thought was not suitable to our department, so we said we don't want. But he came in and now we have to work with him. He is a difficult person (P16)." It appears that the problem is not only about deciding who should be recruited but it is also about when a person should be recruited. To address this issue a chair states "When positions (for new recruitments) became available, I wrote to the dean several times (saying) let's open a position for a (academic) personnel who completed doctoral degree. They said let's wait little more (P12)." This leads chairs to feel a strong need in "having power to open a position (P3)."

\section{Monetary Issues}

Several chairs expressed that the lack of autonomy in monetary issues leads to problems that hinders the effective functioning of departments. One consequence of this problem is that chairs are unable to organize and support academic staff for taking part in academic meetings. In addition, they have difficulty to purchase the essential materials for their laboratories. Chairs comments concurrently point out the conclusion that department chairs need to have their own budget or some level of autonomy in using the faculty budget for academic and social activities.

We don't have any autonomy in the department, sometimes it happens that a guest professor comes for doing a presentation. In order to improve our relations we want to go to dinner together. But we do not have such a budget. If we had such a budget to be used for activities at the department, for scientific (academic activities), also (activities) in which student can be involved, relations could be improved (P15).

\section{Curricular Decisions}

In addition to staff recruitment and monetary issues, few participants highlight the problem of interference in decision-making regarding the content of the courses from the top of the administrative hierarchy and the importance of having autonomy in curricular issues.

The upper administration sometimes takes part in the higher administrative council or the senate, and gives some decisions. For instance, the issue of adding a new course to the curriculum, it sounds good to the faculty administration council. But even the dean may not get acquainted with the content (issues) of the department, the content of courses and accreditation as much as a chair does. In this case, a decision might be given in the council or senate without our consent. They tell us to obey a decision by dictating. This leads to a tension (P14). 
The dean's interference in curricular issues becomes particularly problematic if $\mathrm{h} / \mathrm{she}$ has no academic background compatible with the faculty or the department. For instance, the dean of faculty of fine arts has no academic background in fine arts, therefore, the chair complains that he has trouble in getting the dean accept some activities that are critical for the development of the department. On the other hand, another chair says "Because our dean is also an educator (has a degree from the faculty of education), in most instances he gives decisions regarding the department. We work together. The dean being an educator is beneficial (for us) (P11)."

\section{Additional Personnel}

According to the data, a vast majority of chairs suffer from a considerable balancing problem. Due to the nature of their work which requires focusing on multiple tasks, such as administrative duties and academic improvement, they have trouble in balancing such responsibilities. The main reason for this, as indicated by chairs, is the lack of clerical and academic personnel who share some of their workload. A chair says "What we need the most is the personnel; that is, academic and clerical personnel (P4)." Specifically, it is stressed in the data that they need clerical personnel, such as the secretary, who provide support for administrative duties, and academic personnel, such as the assistant professor, who share their workload in relation to teaching courses.

\section{Clerical Personnel}

The data show that almost all chairs have severe complaints about the formidable managerial workload and hence the extraordinary busy schedules. One participant states

You need a substantial amount of time in order to carry out various activities that could be considered as drudgery by others, including paper-pencil works, meeting students, arranging course exemptions, doing meetings, carrying out department committee meetings, other meetings held by administration (the rector or the dean) (P7).

Participants indicate that they have to take care of all these administrative workload on their own because of the paucity of either an assistant or secretary at the department. A chair says

We (the department) do not have a secretary...in foreign countries there are secretaries and they reduce the workload. We do not have this system. I have done this duty (chairship) abroad for 15 years. I had (a) secretary...they used to do most of the work (P14).

On the other hand, those who have an assistant tend not to complain about heavy workload. For instance, one chair says "We have friends. They are vice department chairs. Thankfully, they are providing support. We are not experiencing (any) problems (P8)."

Although some participants mention the importance of the role that research assistants can play in response to the problem of insufficient clerical personnel, others are critical about having research assistants spend their time on administrative duties since most of them also work on their either dissertation or thesis.

\section{Academic Personnel}

In addition to various administrative duties, chairs are required to undergo a substantial amount of teaching courses due to lack of academic personnel and high number of students enrolled. One chair stated:

In addition to managerial responsibilities, having too much course work is difficult for us. We are six people in the department. We are just a few people and (therefore) the number of course works for each person is high. Both managerial duties and course work are difficult for us...Our problem arises from (high) student teacher ratio (P5). 
The lack of academic and clerical personnel leads to huge workload on chairs, which consequently causes balancing problem. Most chairs emphasize that they have to delay their academic development because of managerial duties. One chair says "I delayed my academic development because I prioritize managerial works (P3)". Another one states "You have to give a decision (whether to) become an effective administrator (chair) or a scholar. Becoming both an effective administrator and effective scholar seems to be impossible for me (P12)."

The data show that department chairs who do not want to give up doing research use the time normally allotted for rest, leisure or their family. The problem is much more severe for female academic leader who states:

You sleep less, do not do the house works that you have to do. This is particularly the case for female chairs. You work out of office hours (and so) hire an assistant (someone who can help with house works). This is economically difficult but male chairs do not have such problems. For a female department chair that is married and has children, this work brings a (substantial) workload (P4).

\section{Training and Orientation}

The last theme emerged as a result of data analysis is the need for training and orientation. There is a particular emphasis on leadership development when chairs mention their need for training. They also mention the need for orientation for both themselves and others, in order for administrative duties to be effectively managed.

\section{Training for Leadership}

The data show that training constitutes the important part of development of academic leaders. However, they also believe that training alone is not sufficient for people to be a leader. Leadership is considered as a characteristic that naturally exists. Therefore, some people are naturally inclined to possess leadership characteristics while others do not. Chairs think that those who have innate leadership skills should occupy chairship positions but also they should be provided with the training opportunities so that they improve their leadership skills. One chair said:

You (department chairs) should be inclined to management in terms of character and personality. I think that this (character and personality) should receive more attention. Character is important. As we say an innate chair, politician, they should be prone (to leadership) in nature. S/he should establish good relations and dialogs with people... Vocational seminars and courses can be provided (to chairs). The person (the chair) can work on self-development. Of course this is a little bit about (his/her) cultural background. In-service training (about) self-development, vocational motivation can be provided (to chairs) (P12).

\section{Orientation for Administrative Duties}

Another problem chair face is the lack of knowledge regarding administrative duties they have to deal with, particularly during the first year of their service. According to chairs, there are two reasons for this problem. The first one is the lack of clarification about roles, responsibilities and authority of chairs. Regarding this issue, one chair says "Duties and responsibilities should be definite. It might be problematic if a scholar in the department is not aware of his responsibilities: What is optional and what is mandatory (P14)." Because the job description of chairs is not clear, "It might be changed (by another one) even if you (chairs) make a decision within the scope of your authority (P7)." The second reason is that chairs take the position without serving as assistant chair previously. "To develop leadership you should go through a certain (administrative) hierarchy. That is, you become an assistant chair and then the chair (P13)." To this end, process of training and orientation during the first year of the service is considered as a beneficial practice for chairs to learn how to deal with managerial issues. 


\section{Conclusion}

Studies on leadership in different sectors have been overwhelming in the last several decades all over the world. While this trend has also impacted on education sector at K-12 level, leadership has still been an understudied phenomenon at higher education level. This has also been the case with Turkey. In this context, the present study aims to explore the needs of department chairs as academic leaders in Turkish universities. In order to achieve this aim, qualitative data were gathered through semi-structured interviews with 16 department chairs. Findings show that needs of department chairs can be categorized under three themes: (a) More autonomy for decision-making in staff recruitment, monetary, and curricular issues (b) Additional academic and clerical personnel, and (c) Training for leadership and orientation for administrative duties.

First of all, department chairs indicate their needs of more autonomy in order to effectively fulfill their leadership roles. In general, they complain about the ambiguity of their roles and extensive interference from upper level administrators, mostly deans, in the departmental issues. Similarly, international literature discuss that department chairs' unique role as being both a faculty member and a leader at the same time, and their mediator position between higher levels of administration and faculty members may cause some autonomy issues and problems in personal relationships (Hecht, 2000; Rowley \& Sherman, 2003; Wolverton et al., 2005). Extant literature also often mention issues such as managing budget, recruiting new faculty members, and designing curriculum as primary responsibilities of department chairs (Bryman, 2007; Cipriano \& Riccardi, 2012; Hecht et al. 1999; Wolverton et al., 2005). However, it seems that Turkish department chairs have limited authority on these issues and they believe that this situation limits their leadership effectiveness.

Second theme arises from the data is the need for additional personnel in both clerical and academic positions. Almost all department chairs mentioned their heavy workload and balancing problem between scholarly activities and administrative tasks. Related literature also mentions balancing issue as one of the most problematic areas for department chairs (Gmelch, 2004; Hecht, 2000; Wolverton et al., 2005). In addition to the balancing problem, participants emphasized that lack of clerical and academic staff makes their job even more difficult. Findings of a recent study about the problems of newly established universities in Turkey also confirm this result. According to rectors of newly established universities in Turkey, one of the most important issues which Turkish universities face is recruiting enough academic and clerical staff (Ozoglu et al., 2016). It is therefore obvious that the lack of enough personnel in Turkish universities make department chairs' job even more problematic, especially in terms of office works and managerial issues.

Lastly, results of this study show that department chairs in Turkish universities need more training and orientation opportunities in order to effectively perform their job. This finding aligns with the common argument in the literature that most department chairs begin their job without enough preparation (Gmelch \& Buller, 2015). Accordingly, studies in other countries such as Australia (Scott, Coates, \& Anderson, 2008), UK (Jackson, 1999), and the USA (Cipriano \& Riccardi, 2012; Gmelch, 2004) indicate that academic leaders, including department chairs, need more development opportunities. Some of the existing studies have also identified the best practices of development activities for academic leaders. These studies indicate that the most effective academic leadership development programs provide practice-based and continuous learning opportunities, mentoring and coaching experiences, and strong peer networks (Gmelch, 2013; Scott et al., 2008; Wolverton et al., 2005). 
To sum up, this study reveals important information about the needs of department chairs as academic leaders in Turkish universities. As discussed earlier, these needs are mostly similar to what have been found in international research, with some contextual differences. However, given the fact that academic leadership is barely studied concept in Turkey, the findings of this study should be justified by future research. There is need for more studies on academic leadership of department chairs, as well as other higher education administrators such as deans and rectors. The needs, expectations, challenges, and practices of these leaders from different perspectives might be explored by using both qualitative and quantitative research approaches, and the results might be compared with international literature. Specific development programs for academic leaders in Turkey could also be another area for future research.

Based on the findings of this study, several recommendations could also be made for policy makers. Given the needs identified by department chairs, it can be suggested that Turkish universities should provide various professional development opportunities to their department chairs. As one chair indicates that the orientation programs should also be organized in a way that experienced chairs work with new ones to help them get used to mandatory workload. Results also show that department chairs need more autonomy in order to effectively perform their job. It is therefore suggested that department chairs should be involved more in decision making processes especially on staff recruitment and monetary issues. In addition, the job descriptions of the department chairs should be made clear, in order to avoid ambiguities and dispensable inferences from upper level administrators. Based on the results of this study, it is also important to provide more clerical staff to departments, especially for the ones in newly established universities in order to have department chairs perform their job more effectively. 


\section{References}

Akbulut, M., Seggie, F. N., \& Börkan, B. (2015). Faculty member perceptions of department head leadership effectiveness at a state university in Turkey. International Journal of Leadership in Education, 18(4), 440-463.

Bowman, R. F. (2002). The real work of the department chair. The Clearing House, 75(3), 158-62. doi:10.1080/00098650209599258

Bryman, A. (2007). Effective leadership in higher education: a literature review. Studies in Higher Education, 32(6), 693-710. doi:10.1080/03075070701685114

Bush, T. (2008). From management to leadership semantic or meaningful change?. Educational Management Administration \& Leadership, 36(2), 271-288. doi:10.1177/1741143207087777

Bush, T. (2011). Succession planning in England: New leaders and new forms of leadership. School Leadership \& Management, 31(3), 181-198. doi:10.1080/13632434.2010.545383

Bush, T., \& Glover, D. (2003). School leadership: Concepts and evidence. Nottingham, UK: National College for School Leadership.

Carroll, J. B., \& Gmelch, W. H. (1994). Department chairs' perceptions of the relative importance of their duties. Journal for Higher Education Management, 10(1), 49-63.

Cipriano, R. E., \& Riccardi, R. (2012). Competencies, challenges, and collegiality: A four-year study of department chairs. The Department Chair, 22(4), 14-17.

Creswell, J. W. (2003). Research design: Qualitative, quantitative, and mixed methods approaches. Thousand Oaks, CA: Sage Publications.

Creswell, J. W. (2007). Qualitative inquiry and research design: Choosing among five approaches. Thousand Oaks, CA: Sage Publications.

Çetinsaya, G. (2014). Büyüme, kalite ve uluslararasılaşma: Türkiye yuikseköğretimi için bir yol haritası. Ankara: Yükseköğretim Kurulu Başkanlığı.

Erkutlu, H., \& Chafra, J. (2014). Ethical leadership and workplace bullying in higher education. Hacettepe Üniversitesi Egĭtim Fakültesi Dergisi, 29(3), 55-67.

Gmelch, W. H. (2002). The call for department leaders. Paper presented at the Annual Meeting of the American Association of Colleges for Teacher Education, New York, NY.

Gmelch, W. H. (2004). The department chair's balancing acts. New Directions for Higher Education, 126, 69-84. doi:10.1002/he.149

Gmelch, W. H. (2013). The Development of Campus Academic Leaders. International Journal of Leadership and Change, 1(1), 25-35.

Gmelch, W. H., \& Buller, J.F. (2015). Building academic leadership capacity: A guide to best practices. San Francisco, CA: Jossey-Bass.

Hallinger, P. (2003). Leading educational change: Reflections on the practice of instructional and transformational leadership. Cambridge Journal of Education, 33(3), 329-352. doi:10.1080/0305764032000122005

Hacifazlioglu, O. (2010). Entry and transition to academic leadership: Experiences of women leaders from Turkey and the US. Educational Sciences: Theory and Practice, 10(4), 2257-2273.

Hecht, I. W. D. (2000). Transitions and transformations: The making of department chairs. In M. Kaplan, \& D. Lieberman (Eds.), To improve the academy: Resources for faculty, instructional and organizational development (pp. 17-31). Bolton, MA: Anker.

Hecht, I. W. D., Higgerson, M. L., Gmelch, W. H., \& Tucker, A. (1999). The Department Chair as Academic Leader. Phoenix, Arizona: American Council on Education Oryx Press.

Jackson, M. P. (1999). The role of the head of department in managing performance in UK universities. The International Journal of Educational Management, 13(3), 142-55. doi:10.1108/09513549910269502 
Kiyik-Kicir, G., \& Paşaoğlu, D. (2014). Otantik liderliğin akademik platformda lider boyutu açısından incelenmesi. Eskişehir Osmangazi Üniversitesi Sosyal Bilimler Dergisi, 15(1), 1-24

Korkut, H. (1992). Üniversite akademik yöneticilerinin liderlik davranışları. Ankara Üniversitesi Eğitim Bilimleri Fakültesi Dergisi, 25(1), 93-111.

Leithwood, K. A., \& Riehl, C. (2003). What we know about successful school leadership. Nottingham, UK: National College for School Leadership.

Lieff, S., Banack, J. G. P., Baker, L., Martimianakis, M. A., Verma, S., Whiteside, C., \& Reeves, S. (2013). Understanding the needs of department chairs in academic medicine. Academic Medicine, 88(7), 960-966. doi:10.1097/ACM.0b013e318294ff36

Marshall, S., Adams, M., \& Cameron, A. (2001). In search of academic leadership. In L. Richardson, \& J. Lidstone (Eds.), Flexible Learning for a Flexible Society (pp. 483-492). Retrieved from http://www.ascilite.org/conferences/aset-archives/confs/aset-herdsa2000/procs/marshall.html

Maxwell, J. A. (2005). Qualitative research design: An interactive approach (2nd ed.). Thousand Oaks, CA: Sage.

Moore, M., \& Diamond, M. (2000). Academic leadership: Turning vision into reality. London, UK: Ernst \& Young Foundation.

Normore, A. H., \& Brooks, J. S. (2014). The Department Chair: A Conundrum of Educational Leadership versus Educational Management. In A. I. Lahera, K. Hamdan, \& A. H. Normore (Eds.), Pathways to Excellence: Developing and Cultivating Leaders for the Classroom and Beyond (pp. 319). Bingley, UK: Emerald Group Publishing Limited.

Ozoglu, M., Gur, B. S., \& Gumus, S. (2016). Rapid expansion of higher education in Turkey: The challenges of recently established public universities (2006-2013). Higher Education Policy, 29(1), 21-39.

Parker, R. (December 3, 2014). Leadership tips for university department chairs: Setting the right tone and putting faculty first are key. Retrieved from http://www.universityaffairs.ca/careeradvice/career-advice-article/leadership-tips-university-department-chairs/

Patton, M. Q. (2002). Qualitative research \& evaluation methods. Thousand Oaks, CA: Sage

Rowley, D. J., \& Sherman, H. (2003). The special challenges of academic leadership. Management Decision, 41(10), 1058-1063. doi:10.1108/00251740310509580

Sathye, M. (September, 2004). Leadership in higher education: A qualitative study. Forum Qualitative Sozialforschung / Forum: Qualitative Social Research, 5(3). Retrieved from http://www.qualitativeresearch.net/index.php/fqs/article/view/571

Scott, G., Coates, H., \& Anderson, M. (2008). Academic Leadership Capabilities for Australian Higher Education. Sydney, Australia: Australian Learning and Teaching Council.

Sirin, E. F., \& Yetim, A. A. (2009). Beden eğitimi ve spor yüksekokulu yöneticilerinin dönüşümcü liderlik stiline ilişkin yönetici algıları. Beden Eğitimi ve Spor Bilimleri Dergisi, 3(1) 69-84.

Sirkis, J. E. (2011). Development of leadership skills in community college department chairs. The Community College Enterprise, 17(2), 46-61.

Üniversitelerde Akademik Teşkilat Yönetmeliği. (1982). T. C. Resmi Gazete, 17609, 18 Şubat 1982.

Winston, B. E., \& Patterson, K. (2006). An integrative definition of leadership. International Journal of Leadership Studies, 1(2), 6-66.

Wolverton, M., Ackerman, R., \& Holt, S. (2005). Preparing for leadership: What academic department chairs need to know. Journal of Higher Education Policy and Management, 27(2), 227-238. doi:10.1080/13600800500120126

Wolverton, M., \& Gmelch, W. H. (2002). College Deans: Leading from within. American Council on Education/Oryx Press Series on Higher Education. Westport, CT: Oryx Press.

YÖK, (2015). Higher education information management system. Retrieved from https://istatistik.yok.gov.tr/ 